\title{
PEMODELAN INTRUSI AIR ASIN PADA AKUIFER PANTAI (STUDI KASUS: DKI JAKARTA)
}

\section{SALT WATER INTRUSION MODELING IN COASTAL AQUIFERS (CASE STUDY: DKI JAKARTA)}

\author{
Alan Wijaya' ${ }^{1)}$ Arno Adi Kuntoro') Edy Anto Soentoro Gondodinoto' \\ 1) Institut Teknologi Bandung \\ Jl. Tamansari No. 64, Tamansari 40116, Bandung, Indonesia \\ E-Mail: alanks3m@gmail.com
}

Diterima: 7 November 2018; Direvisi: 1 Juli 2019; Disetujui: 8 Juli 2019

\begin{abstract}
Main issues frequently faced by communities living in the city of Jakarta is salt water intrusion. This paper analyzes the extent of the distribution of saltwater contamination to coastal aquifers in Jakarta, the method used is the open source program FREEWAT. modeling is carried out in five scenarios, namely (1) reduction of 50\% of groundwater use, (2) reduction of 25\% of groundwater use, (3) existing groundwater use in 2012, (4) increase of 25\% of groundwater use, and (5) increase of 50\% of groundwater use. From the modeling results, the distribution of saltwater contamination on each layer of the aquifer of Jakarta. In unconfined aquifer the existing condition is scenario 3 intrusion as far as $1.604 \mathrm{~m}$, on scenario 1 there is an intrusion decrease of 38\%, in scenario 2 there is an intrusion decrease of 13\%, in scenario 4 there is an increase in intrusion by $17 \%$ and on scenario 5 increase intrusion by 25\%. In upper confined aquifer, the existing condition, namely scenario 3, has occurred as much as $1.809 \mathrm{~m}$ intrusion, in scenario 1 there is an intrusion decrease of $23 \%$, in scenario 2 there is an intrusion decrease of $8 \%$, in scenario 4 there is an increase in intrusion by $19 \%$ and in scenario 5 increase intrusion by 26\%. In middle confined aquifer, the existing condition is scenario 3, $1.927 \mathrm{~m}$ intrusion occurs, on the scenario 1 there is an intrusion decrease of 23\%, in scenario 2 there is an intrusion decrease of $9 \%$, in scenario 4 there is an increase in intrusion by $16 \%$ and in the scenario 5 increase intrusion by $22 \%$.
\end{abstract}

Keywords: Groundwater, Intrusion, Salt Water, FREEWAT, Jakarta

\begin{abstract}
ABSTRAK
Masalah yang kerap dihadapi oleh masyarakat di Kota Jakarta adalah intrusi air laut. Naskah ini menganalisis sejauh mana distribusi kontaminasi air asin terhadap akuifer pantai di Jakarta, menggunakan metode program open source FREEWAT. Pemodelan dilakukan dalam 5 skenario, yaitu: (1) Pengurangan 50\% penggunaan air tanah, (2) Pengurangan 25\% penggunaan air tanah, (3) Penggunaan air tanah eksisting tahun 2012, (4) Peningkatan 25\% penggunaan air tanah, dan (5) Peningkatan 50\% penggunaan air tanah. Hasil pemodelan diperoleh pada akuifer tidak tertekan, kondisi eksisting yaitu skenario 3 terjadi intrusi sejauh $1.604 \mathrm{~m}$, skenario 1 terjadi penurunan intrusi sebesar 38\%, skenario 2 terjadi penurunan intrusi sebesar 13\%, skenario 4 terjadi peningkatan intrusi sebesar 17\% dan skenario 5 peningkatan intrusi sebesar 25\%. Pada akuifer tertekan atas, kondisi eksisting yaitu skenario 3 terjadi intrusi sejauh 1.809 m, skenario 1 terjadi penurunan intrusi sebesar 23\%, skenario 2 terjadi penurunan intrusi sebesar 8\%, skenario 4 terjadi peningkatan intrusi sebesar 19\% dan skenario 5 peningkatan intrusi sebesar 26\%. Pada akuifer tertekan tengah, kondisi eksisting yaitu skenario 3 terjadi intrusi sejauh 1.927 m, skenario 1 terjadi penurunan intrusi sebesar 23\%, skenario 2 terjadi penurunan intrusi sebesar 9\%, skenario 4 terjadi peningkatan intrusi sebesar 16\% dan skenario 5 peningkatan intrusi sebesar $22 \%$.
\end{abstract}

Kata Kunci: $\quad$ Air Tanah, Intrusi, Air asin, FREEWAT, Jakarta,

DOI 


\section{PENDAHULUAN}

Ada beberapa persoalan lingkungan yang kerap dihadapi oleh masyarakat yang mendiami kawasan pesisir pantai di Indonesia khususnya di Kota Jakarta, salah satunya adalah intrusi air asin. Hal ini terjadi di mana air tanah sedang dipompa dari akuifer yang ada dalam hidrolik dengan laut, gradien diinduksi dapat menyebabkan migrasi dari air garam dari laut menuju air tawar, membuat air tawar yang tidak dapat digunakan. Eksploitasi air tanah secara berlebihan dan tidak terkontrol dapat menyebabkan turunnya permukaan tanah diakibatkan oleh hilangnya air yang mengisi rongga pada butiran tanah. Selain itu kerusakan lingkungan lain yang masih memiliki keterkaitan dengan masalah penurunan tanah adalah intrusi air asin. Intrusi air asin ini merupakan pergerakan air asin ke akuifer air tawar yang dapat mengkontaminasi sumber air minum. Penyebab terjadinya intrusi air asin ini adalah pengambilan air tanah dari akuifer pantai yang dapat meningkatkan intrusi air laut karena tekanan air tanah berkurang dan menjadi relatif lebih kecil dibandingkan tekanan dari air laut.

Berdasarkan Badan Pusat Statistik (BPS), jumlah penduduk DKI (Daerah Khusus Ibu Kota) Jakarta pada tahun 2015 mencapai 10,8 juta jiwa, kemudian meningkat menjadi 10,28 juta jiwa pada tahun 2016, dan bertambah menjadi 10,37 juta jiwa pada tahun 2017. Artinya pertumbuhan jumlah penduduk di Kota Jakarta sangat signifikan. Selama dua tahun terakhir jumlah penduduk bertambah 269 jiwa setiap hari atau 11 orang per jam (BPS, 2018).

Perkembangan penduduk dan pertumbuhan industri, bisnis, serta pemukiman yang pesat tentunya berbanding lurus dengan peningkatan jumlah kebutuhan air bersih sedangkan perubahan lahan akan mengurangi wilayah yang menjadi resapan air. Rendahnya kemampuan Perusahaan Air Minum (PAM) dalam menyediakan air bersih, yang masih berkisar $40 \%$ dan belum mengalami perkembangan yang signifikan menyebabkan penduduk dan masyarakat komersial mengambil sumber air tanah, yang mana struktur akuifer Jakarta dengan struktur lapisan akuifer relatif datar dan merupakan akuifer pesisir pantai menyebabkan wilayah Jakarta merupakan wilayah yang rawan untuk terjadinya intrusi air asin.

Berdasarkan uraian di atas, terdapat beberapa masalah pokok yang berkaitan dengan pengelolaan sumber daya air tanah di Jakarta, yaitu jumlah penduduk yang besar, pertumbuhan industri dan bisnis yang pesat, ketersediaan sumber daya air tanah dan kemampuan PAM yang masih sangat terbatas, dan posisi Jakarta dengan sistem akuifernya berbatasan dengan pantai. Masalah-masalah pokok tersebutlah yang menyebabkan intrusi air asin di Jakarta semakin jauh masuk ke sistem akuifer air tanah tawar, sehingga diperlukannya tindakan yang tegas dari pemerintah DKI Jakarta dalam pemeliharaan lingkungan guna menjaga kualitas dan kuantitas air tanah itu sendiri dan peran serta dari masyarakat dalam pemeliharaan lingkungan tersebut.

Jumlah keberlanjutan airtanah akhir-akhir ini di Jakarta masih dalam tingkat kritis. Tanpa adanya intervensi jumlah air tanah masih terus mengalami penurunan dari tahun ke tahun (Wahyudi \& Moersidik, 2015). Pada hasil penelitan terdahulu (Setiawan, dkk, 2017) menunjukan pada akuifer tertekan atas intrusi terjadi kurang dari 3.000 meter dan pada akuifer tertekan tengan sejauh kurang dari 9.000 meter dengan sifat sedikit asin.

Tujuan dari penelitian ini adalah untuk menganalisis sejauh mana distribusi kontaminasi air asin terhadap akuifer pantai di Jakarta. Hasil akhir yang ingin dicapai pada penelitian ini adalah prediksi dari pemodelan yang dilakukan dapat mendekati kondisi sebenarnya di lapangan.

\section{METODOLOGI}

\section{Pengumpulan Data}

Data-data yang digunakan berupa data sekunder yang di-peroleh dari instansi terkait dan internet yang sifatnya bebas untuk digunakan.

Tabel 1 Data-data sekunder yang digunakan

\begin{tabular}{|c|c|c|c|}
\hline No & $\begin{array}{l}\text { Jenis } \\
\text { Peta/Data }\end{array}$ & Sumber Data & Keterangan \\
\hline 1 & Peta Geologi & DGTL Bandung & 1 Peta \\
\hline 2 & $\begin{array}{l}\text { Peta } \\
\text { Hidrogeologi }\end{array}$ & DGTL Bandung & 1 Peta \\
\hline 3 & $\begin{array}{l}\text { Data Spasial } \\
\text { Wilayah } \\
\text { Administrasi }\end{array}$ & $\begin{array}{l}\text { Badan } \\
\text { Penanggulangan } \\
\text { Bencana Daerah }\end{array}$ & $\begin{array}{l}1 \text { Data } \\
\text { Kecamatan }\end{array}$ \\
\hline & $\begin{array}{l}\text { DKI Jakarta } \\
\text { dan Sungai. }\end{array}$ & $\begin{array}{l}\text { (BPBD) DKI } \\
\text { Jakarta }\end{array}$ & $\begin{array}{l}\text { dan } \\
\text { Provinsi }\end{array}$ \\
\hline 4 & $\begin{array}{l}\text { Data Lokasi } \\
\text { Pompa }\end{array}$ & $\begin{array}{l}\text { Jakarta Open } \\
\text { Data }\end{array}$ & - \\
\hline 5 & $\begin{array}{l}\text { Data DEM 12,5 } \\
\text { m Alos Palsar }\end{array}$ & $\begin{array}{l}\text { Alaska Satellite } \\
\text { Facility }\end{array}$ & $\begin{array}{l}1 \quad \text { DEM } \\
\text { Jakarta }\end{array}$ \\
\hline 6 & $\begin{array}{l}\text { Data Kualitas } \\
\text { Air Tanah } \\
\text { Data }\end{array}$ & $\begin{array}{l}\text { Balai Konservasi } \\
\text { Air Tanah }\end{array}$ & $\begin{array}{l}\text { Data tahun } \\
2017\end{array}$ \\
\hline 7 & $\begin{array}{l}\text { Penggunaan } \\
\text { Air Tanah }\end{array}$ & $\begin{array}{l}\text { Geomagz, } \\
(2014)\end{array}$ & - \\
\hline
\end{tabular}




\section{Pemodelan FREEWAT}

Pemodelan FREEWAT dibuat berdasarkan evaluasi dan analisis data geologi, hidrogeologi, topografi serta konfigurasi dan parameter sistem akuifer daerah penelitian. Guna memperoleh distribusi sebaran intrusi air asin, digunakan 2 modul pada FREEWAT. Modul MODFLOW-2005 untuk memodelkan aliran air tanah dan model SEAWAT untuk memodelkan Solute Transport atau intrusi air asin. Berikut persamaan diferensial parsial untuk akuifer terbatas digunakan dalam MODFLOW adalah (Harbaugh, 2005).

$\frac{\partial}{\partial x}\left[K_{x x} \frac{\partial h}{\partial x}\right]+\frac{\partial}{\partial y}\left[K_{y y} \frac{\partial h}{\partial y}\right]+\frac{\partial}{\partial z}\left[K_{z z} \frac{\partial h}{\partial z}\right]+W=S_{s} \frac{\partial h}{\partial t} \ldots$

dimana:

$\mathrm{K}_{\mathrm{xx}}, \mathrm{K}_{\mathrm{yy}}$, dan $\mathrm{K}_{\mathrm{zz}}$ : nilai konduktivitas hidrolik sepanjang sumbu koordinat $\mathrm{x}, \mathrm{y}$, dan $\mathrm{z}$ (L/T);

h : nilai potensiometrik head (L);

W : fluks volumetrik per satuan volume yang mewakili sumber dan/atau tenggelamnya air, dimana nilai negatifnya adalah ekstraksi, nilai positif adalah injeksi ( $\left.\mathrm{T}^{-1}\right)$;

$\mathrm{S}_{\mathrm{s}} \quad$ : penyimpanan spesifik dari bahan berpori $\left(\mathrm{L}^{-1}\right)$; dan

t : waktu (T).

Sedangkan pada SEAWAT (Guo \& Langevin, 2002), kode SEAWAT adalah MODFLOW dan
MT3DMS digabungkan menjadi satu program yang dapat menyelesaikan persamaan gabungan dan persamaan transport terlarut. Bagian dari kode MODFLOW asli dimodifikasi untuk memasukkan persyaratan perbedaan kerapatan relatif dan istilah yang mengkuantifikasi laju akumulasi massa karena perubahan konsentrasi zat terlarut, dan keseluruhan persamaan aliran dirumuskan kem-bali untuk menghemat massa dan bukan volume cairan. Kopling antara aliran dan transportasi dilakukan melalui pendekatan time stepping sinkron yang menghubungkan antara solusi MODFLOW dari persamaan aliran dan solusi MT3DMS dari persamaan transportasi.

Diagram pada gambar 1 menunjukan bagaimana modul MODFLOW dan SEAWAT pada FREEWAT saling berhubungan, dengan mengambil acuan standar prosedur pemodelan.

Dalam pemodelan intrusi air asin pada akuifer pantai DKI Jakarta yang dilakukan dengan 5 skenario model, yaitu : (1) Pengurangan 50\% dari penggunaan air tanah, (2) Pengurangan 25\% dari penggunaan air tanah, (3) Penggunaan air tanah eksisting tahun 2012, (4) Peningkatan 25\% dari penggunaan air tanah, dan (5) Peningkatan $50 \%$ dari penggunaan air tanah. Adapun untuk gambaran dari skema pemodelan dapat dilihat pada gambar berikut ini.

Berdasarkan gambar skema model pada gambar 2, potongan melintang sangat membantu dalam pembuatan suatu basis model. Adapun potongan melintang berdasarkan gambar skema di atas adalah dapat dilihat pada gambar 3 .

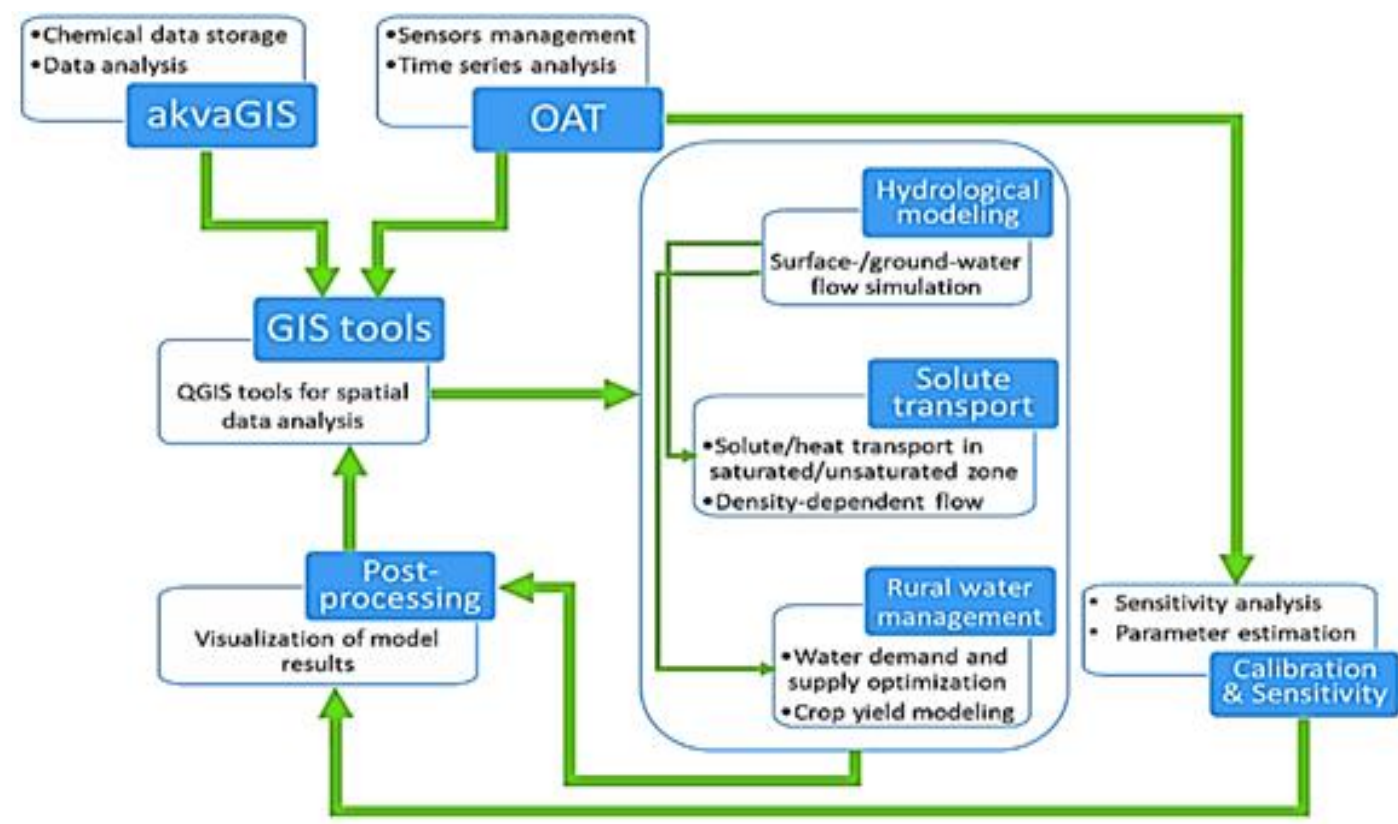

Sumber: Filippis, et al., 2017

Gambar 1 Diagram hubungan antar modul dengan menggunakan acuan standar pemodelan 


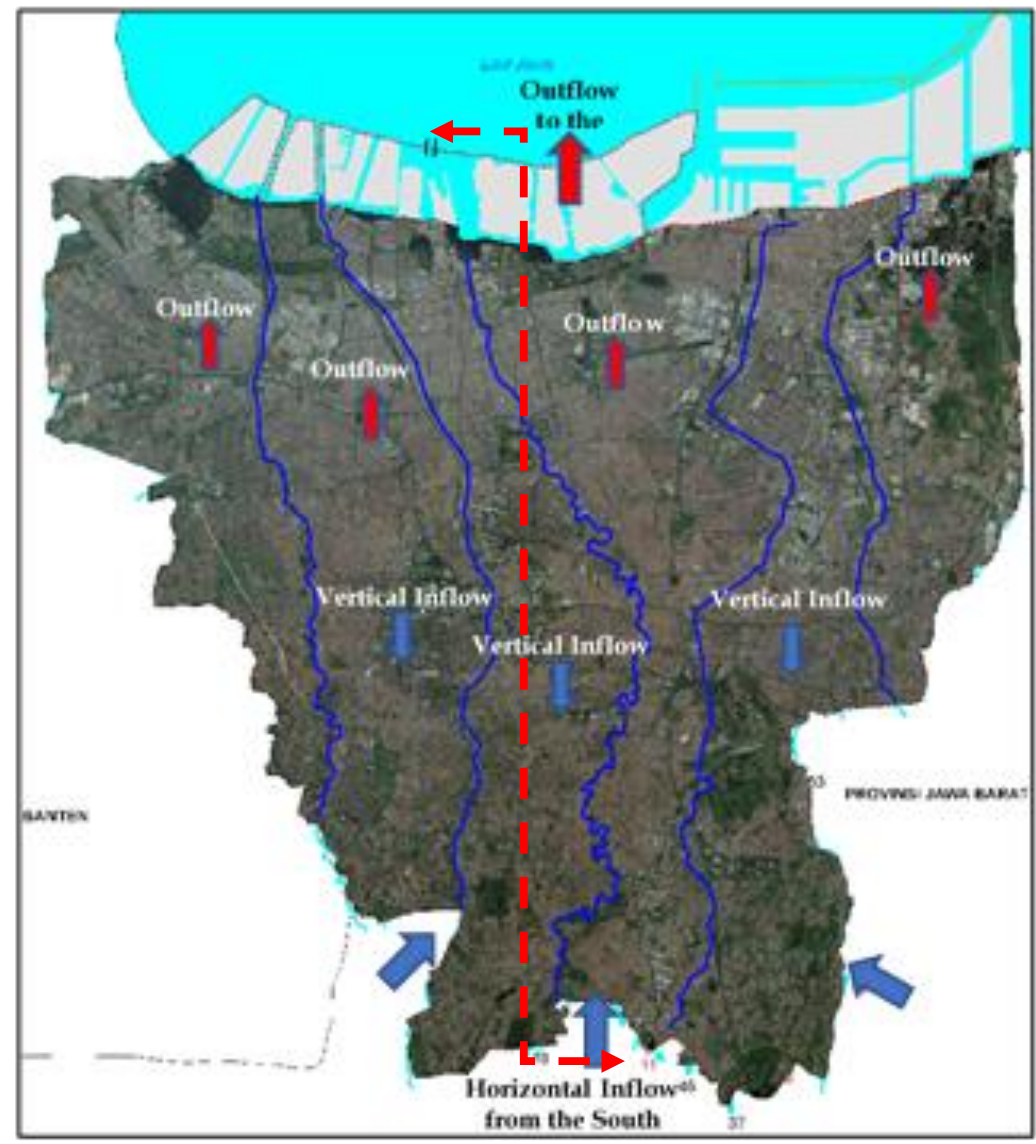

Gambar 2 Skema model pada wilayah penelitian

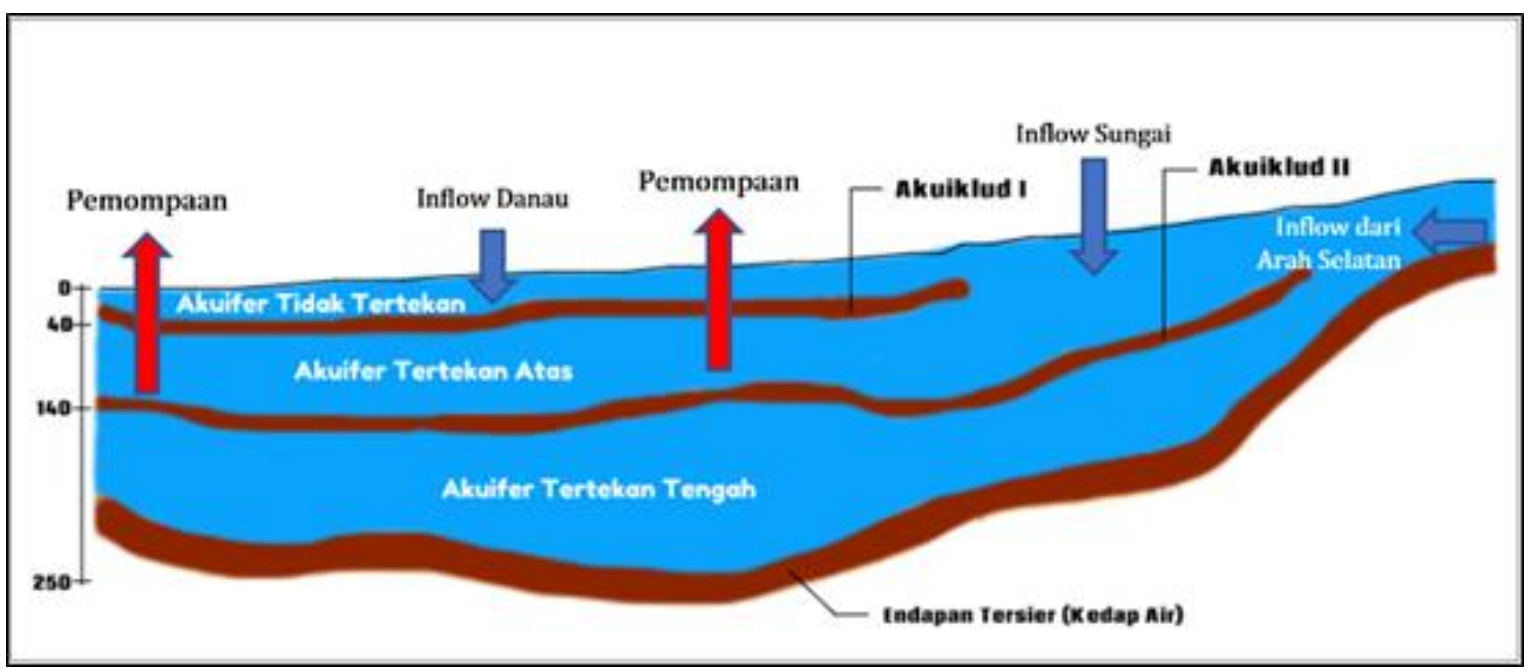

Gambar 3 Potongan melintang skema model

Model dibuat dalam 3 lapisan dikarenakan lapisan pem-batas antara masing-masing lapisan akuifer (akuiklud) tidak sepenuhnya membatasi antar akuifer dan akuiklud ini memiliki potensi bocor karena lapisan akuiklud merupakan lempung pasiran atau lempung tufaan sehingga masih memiliki potensi untuk meloloskan air dari lapisan akuifer ke akuifer lainnya. Hal ini terjadi akibat pengendapan Jakarta tidak terjadi dalam 1 sikuen pengendapan, tetapi terjadi dari sikuen yang berulang-ulang (Mukhtar, Pranantya, \& 
Hadian, 2016). Adapun lapisan tersebut adalah sebagai berikut :

1 Unconfined aquifer atau akuifer tidak tertekan, dengan ketebalan 0 - 40 m dengan struktur lapisan terdiri dari lanau, pasir dan kerikil.

2 Top confined aquifer atau lapisan akuifer tertekan atas, dengan ketebalan 40 - 140 m dan struktur lapisan terdiri dari lempung dengan sisipan tipis pasir andesit.

3 Middle confined aquifer atau lapisan akuifer tertekan ten-gah, dengan ketebalan 140 - 250 $m$ dan struktur lapisan terdiri dari lempung dengan sisipan tipis pasir andesit dan pasir kwarsa.

Kondisi awal pada pemodelan yaitu nilai head akan diatur berdasarkan nilai muka air tanah pada masing-masing lapisan akuifer tahun 2010 . Pada akuifer tak tertekan kedalaman muka air tanah antara 0,48 dan 12,14 meter, pada akuifer tertekan atas antara 8,07 dan 54,16 meter dan pada akuifer tertekan tengah/bawah antara 0,12 - 58,8 meter (Matahelumual, 2010).

Penggunaan air tanah paling banyak dilakukan dari akuifer produktif yaitu akuifer tertekan atas (Wandowo dkk, 2001), sehingga pada pemodelan ini, sumur produksi disimulasikan pada lapisan akuifer tertekan atas.

Nilai Kx pada daerah Jakarta Utara adalah berkisar 6,5 x 10-4 sampai dengan 2,9 m/hari, sedangkan untuk Jakarta bagian tengah berkisar 1,32 x 10-4 sampai dengan 2,3 m/hari, serta pada daerah Jakarta Selatan berkisar antara 1,4 x 10-4 sampai dengan 1,1 m/hari (Herlambang \& Indriatmoko, 2005).
Nilai porositas berkisar 0.3 dan 0.7 dengan asumsi bahwa tanah adalah kontinum. Porositas dapat dianggap sebagai fungsi posisi (Nimmo, 2004).

Setelah skema dari model dibuat, kemudian menentukan Boundary Conditions atau kondisi batas pada model tersebut. Adapun kondisi batas untuk mensimulasikan aliran air tanah dan intrusi air asin adalah sebagai berikut :

1 Inflow dari arah selatan, yaitu dari arah Depok dan Bogor yang didefinisikan sebagai Well (WEL) pada FREEWAT yang merupakan debit positif.

2 Inflow dari kali Pesanggrahan, kali Krukut, kali Cili-wung, kali Cipinang, dan kali Kramat Jati yang didefin-iskan sebagai River (RIV) pada FREEWAT.

3 Pemompaan air tanah untuk kebutuhan air baku masyarakat maupun industri dan bisnis didefinisikan sebagai Well (WEL) pada FREEWAT yang merupakan debit negatif.

4 Recharge (RCH) dari waduk-waduk yang ada di Jakarta dengan besarnya sebaran nilai recharge dapat dilihat pada gambar 4. Pada point ini, recharge bukan berasal dari hujan. Pada model ini recharge dari hujan dia-baikan karena mengingat tataguna lahan pada DKI Jakarta sebagian besar adalah pemukiman, yang berarti daerah resapan air sangat sedikit. Pertimbangan lain adalah bahwa proses masuknya air hujan kedalam lapisan akuifer membutuhkan waktu yang lama dan adanya kejadian evaporasi sehingga diabaikan.

5 Outflow berada pada daerah Jakarta Utara yang mengarah ke Laut Jawa didefinisikan sebagai Con-stant-head (CHD).

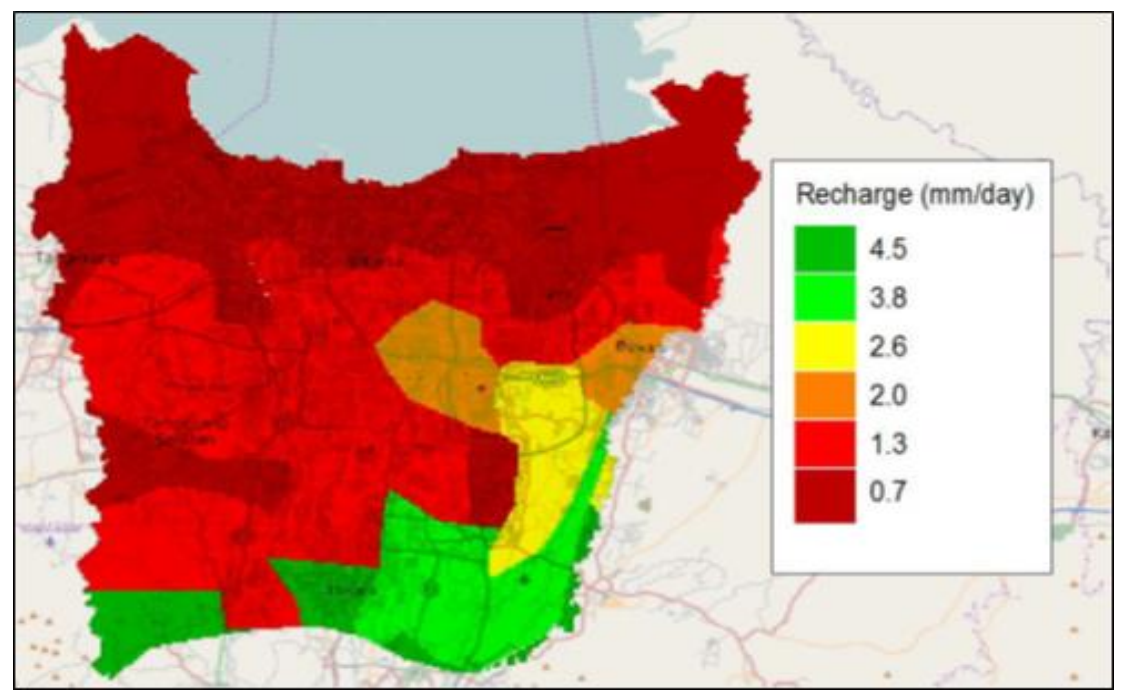

Gambar 4 Nilai reacharge (RCH) (Roover, 2015) 


\section{Kalibrasi Model}

Kalibrasi model dilakukan untuk memvalidasi hasil model agar saling berkesesuaian antar keduanya. Data yang digunakan untuk memvalidasi model adalah dengan menggunakan data kualitas air tanah yang diperoleh dari Balai Konservasi Air Tanah. Pada data tersebut, yang digunakan adalah data pada sumur produksi dan sumur pantau yang mana sumur-sumur tersebut merupakan sumur pada akuifer tertekan dengan membandingkan nilai natrium klorida atau kadar garamnya.

\section{HASIL DAN PEMBAHASAN}

\section{Pengambilan Air Tanah}

Penggunaan air tanah di DKI Jakarta sesuai dengan skenario yang disebutkan pada Metode Penelitian dapat dilihat pada grafik di bawah ini. Berdasarkan grafik dapat dilihat bahwa penggunanaan air tanah pada skenarion 1 yaitu sebesar $62.500 \mathrm{~m}^{3} /$ hari, skenario 2 yaitu sebesar $93.750 \mathrm{~m}^{3} /$ hari, skenarion 3 yang merupakan kondisi eksisting tahun 2012 yaitu sebesar $125.000 \mathrm{~m}^{3} /$ hari, skenario 4 yaitu sebesar $156.250 \mathrm{~m}^{3} /$ hari, dan skenario 5 yaitu sebesar $187.500 \mathrm{~m}^{3} /$ hari yang ditunjukan pada gambar berikut ini.

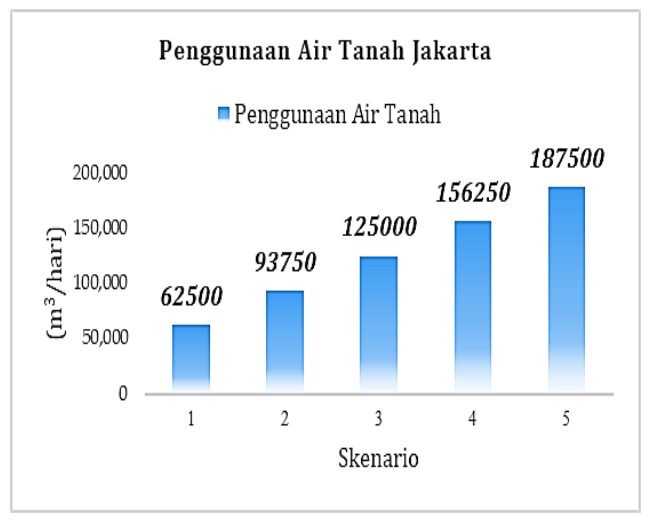

Gambar 5 Penggunaan air tanah Jakarta dari 5 skenario

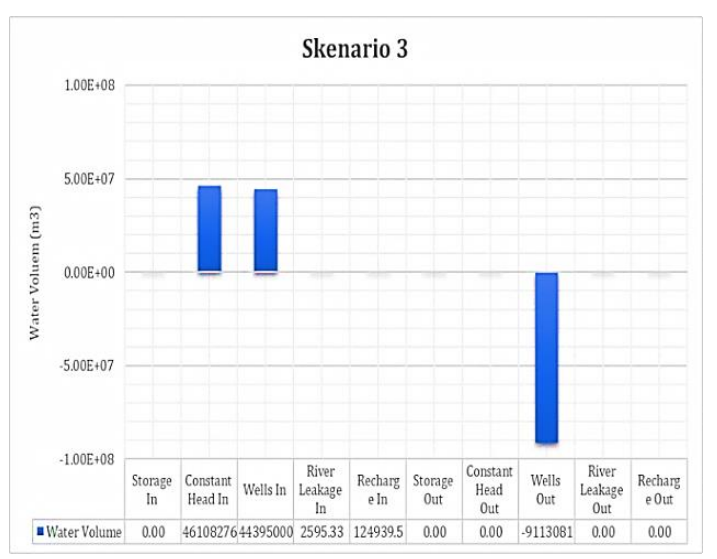

Gambar 6 Output volumetric budget skenario 3

\section{Output Model FREEWAT}

a. Pemodelan Air Tanah

Tabel 2 Output aliran air tanah skenario 3

\begin{tabular}{|c|c|c|c|}
\hline $\begin{array}{l}\text { Cumulative } \\
\text { Volumes }\end{array}$ & $\mathrm{L}^{* * 3}$ & $\begin{array}{c}\text { Rates For } \\
\text { This Time } \\
\text { Step }\end{array}$ & $\mathrm{L}^{* * 3 / \mathrm{T}}$ \\
\hline In : & & \multirow{7}{*}{$\begin{array}{r}\text { In : } \\
\text { Storage = } \\
\text { Constant } \\
\text { Head = } \\
\text { Wells = } \\
\text { River } \\
\text { Leakage = } \\
\text { Recharge = } \\
\text { Total In = }\end{array}$} & \multirow{7}{*}{$\begin{array}{r}0.00 \\
126324.05 \\
123000.00 \\
7.11 \\
342.30 \\
249673.47\end{array}$} \\
\hline Storage $=$ & 0.00 & & \\
\hline $\begin{array}{r}\text { Constant } \\
\text { Head = }\end{array}$ & 46108276.00 & & \\
\hline Wells = & 44395000.00 & & \\
\hline $\begin{array}{r}\text { River } \\
\text { Leakage }=\end{array}$ & 2595.33 & & \\
\hline Recharge $=$ & 124939.51 & & \\
\hline Total $\ln =$ & 91130816.00 & & \\
\hline Out : & \multirow{5}{*}{91130816.00} & \multirow{7}{*}{$\begin{array}{r}\text { Out : } \\
\text { Storage = } \\
\text { Constant } \\
\text { Head = } \\
\text { Wells = } \\
\text { River } \\
\text { Leakage = } \\
\text { Recharge = } \\
\text { Total In = }\end{array}$} & \multirow{7}{*}{$\begin{array}{r}249673.47 \\
0.00 \\
0.00 \\
249673.47\end{array}$} \\
\hline Storage $=$ & & & \\
\hline $\begin{array}{r}\text { Constant } \\
\text { Head = }\end{array}$ & & & \\
\hline Wells = & & & \\
\hline $\begin{array}{r}\text { River } \\
\text { Leakage }=\end{array}$ & & & \\
\hline Recharge $=$ & 0.00 & & \\
\hline Total $\ln =$ & 91130316.00 & & \\
\hline $\begin{array}{r}\text { In-Out }= \\
\text { Percent }\end{array}$ & 0.0000 & $\begin{array}{r}\text { In }- \text { Out }= \\
\text { Percent }\end{array}$ & 0.0000 \\
\hline Discrepancy & 0.00 & Discrepancy & 0.00 \\
\hline$=$ & & $=$ & \\
\hline
\end{tabular}

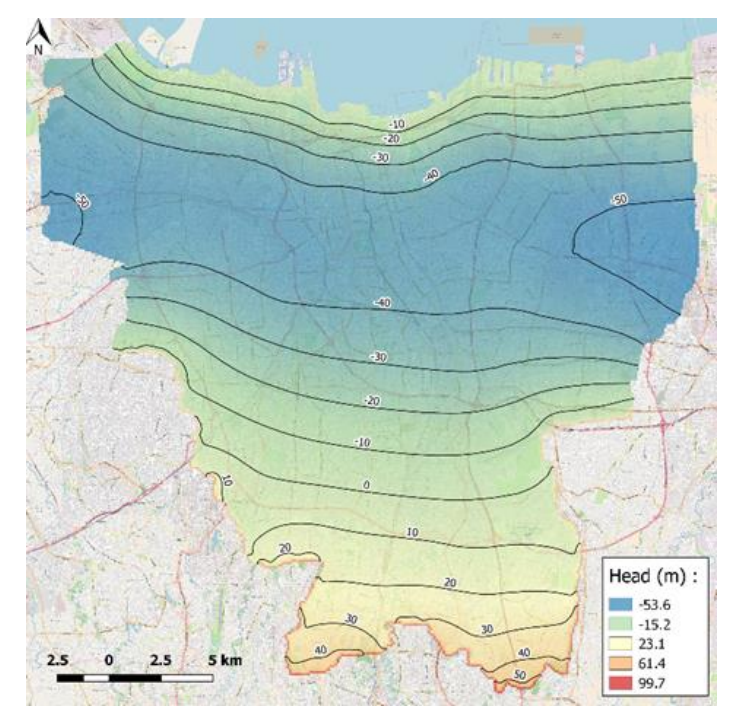

Gambar 7 Head akuifer tak tertekan skenario 3 


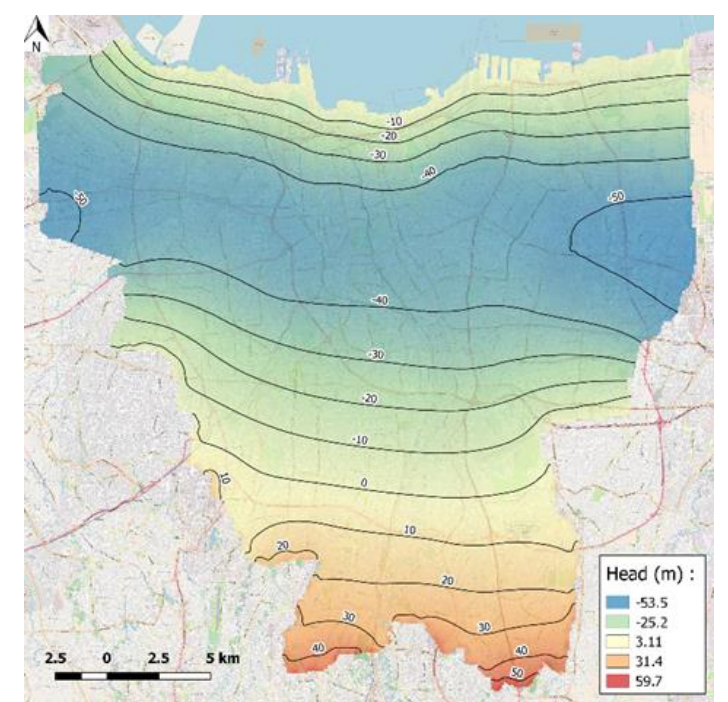

Gambar 8 Head akuifer tertekan atas skenario 3

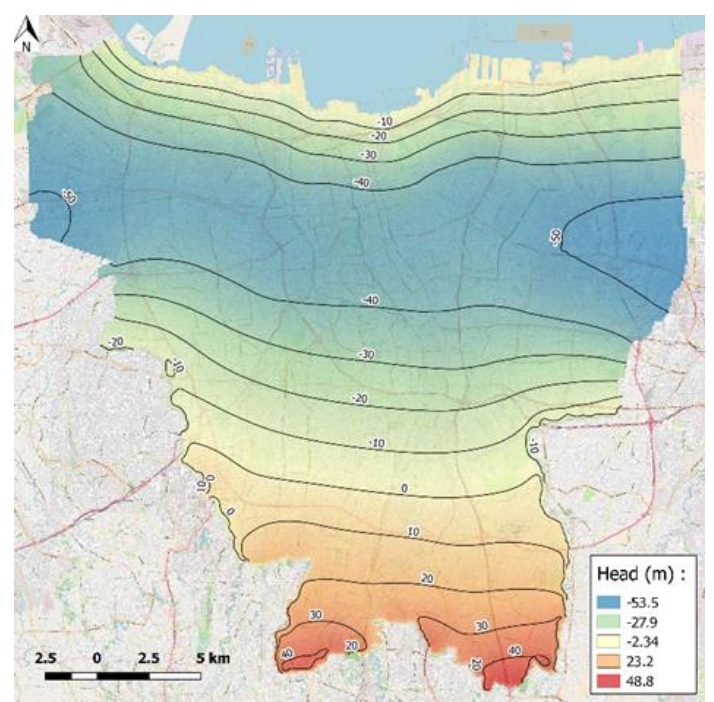

Gambar 9 Head akuifer tertekan tengah skenario 3

Tabel 3 Volumetric budget dari 5 skenario model

\begin{tabular}{|c|c|c|c|c|c|}
\hline Budget Term & $\begin{array}{c}\text { Skenario } 1 \\
\left(\mathrm{~m}^{3} / \mathrm{hari}\right)\end{array}$ & $\begin{array}{c}\text { Skenario } 2 \\
\left(\mathrm{~m}^{3} / \text { hari }\right)\end{array}$ & $\begin{array}{l}\text { Skenario } 3 \\
\left(\mathrm{~m}^{3} / \text { hari }\right)\end{array}$ & $\begin{array}{c}\text { Skenario } 4 \\
\left(\mathrm{~m}^{3} / \text { hari }\right)\end{array}$ & $\begin{array}{c}\text { Skenario } 5 \\
\left(\mathrm{~m}^{3} / \text { hari }\right)\end{array}$ \\
\hline Constant Head In & $6.598,97$ & $64.023,86$ & $126.324,05$ & $188.740,56$ & $251.164,64$ \\
\hline Wells In & $123.000,00$ & $123.000,00$ & $123.000,00$ & $123.000,00$ & $123.000,00$ \\
\hline River Leakage In & 1,82 & 5,25 & 7,11 & 7,11 & 7,11 \\
\hline Recharge In & 342,30 & 342,30 & 342,30 & 342,30 & 342,30 \\
\hline Total In & $129.943,09$ & $187.371,41$ & $249.673,47$ & $312.089,97$ & $374.514,06$ \\
\hline $\begin{array}{l}\text { Constant Head } \\
\text { Out }\end{array}$ & $-4.839,32$ & 0 & 0 & 0 & 0 \\
\hline Wells Out & $-125.052,93$ & $-187.363,36$ & $-249.673,47$ & $-312.090,03$ & $-374.514,16$ \\
\hline $\begin{array}{l}\text { River Leakage } \\
\text { Out }\end{array}$ & $-51,05$ & $-8,29$ & 0 & 0 & 0 \\
\hline Total Out & $129.943,30$ & 187.371,64 & $249.673,47$ & $312.090,03$ & $374.514,16$ \\
\hline In-Out & $-0,20$ & $-0,23$ & 0,00 & $-0,06$ & $-0,09$ \\
\hline
\end{tabular}

Berdasarkan hasil dari pemodelan di atas, dapat dilihat bahwa pada setiap lapis akuifer yaitu akuifer tidak tertekan, akuifer tertekan atas, dan akuifer tertekan tengah dari masing-masing skenario memiliki head yang relatif sama. Dimana pada model dibuat kondisi awal head pada masing-masing lapis akuifer berbeda-beda yang sesuai dengan kondisi awal dari head pada Metode Penelitian. Ini disebabkan karena model dibangun dengan mengabaikan akuiklud. Lapisan akuiklud diabaikan dikarenakan lapisan akuiklud pada wilayah penelitian tidak sepenuhnya membatasi antar akuifer, akuiklud pada wilayah penelitian ini memiliki potensi bocor karena merupakan lempung pasiran sehingga masih ada potensi untuk meloloskan air ke akuifer lainnya. Hal tersebutlah yang membuat hasil head dari pemodelan dari setiap lapis akuifer pada setiap scenario memiliki head yang sama (Mukhtar, Pranantya, \& Hadian, 2016).

Untuk sebagai perbandingan head air tanah hasil simulasi dengan histori data head pada akuifer dalam yaitu tahun 2004 dan 2008 dimana terjadi depresi muka iar tanah yaitu -15 meter dan -25 meter. Sedangkan pada pemodelan yaitu pada kondisi eksisting (skenario 3) terjadi depresi muka air tanah -50 meter. Apabila histori head dan head hasil pemodelan dibandingkan maka akan nampak perbedaan pola dari head. Perbedaan pola ini diakibatkan tidak seragamnya data sebaran dan debit pengambilan air tanah dari sumur pompa, sehingga menyebabkan perbedaan pola antara head histori dan head dari pemodelan. 

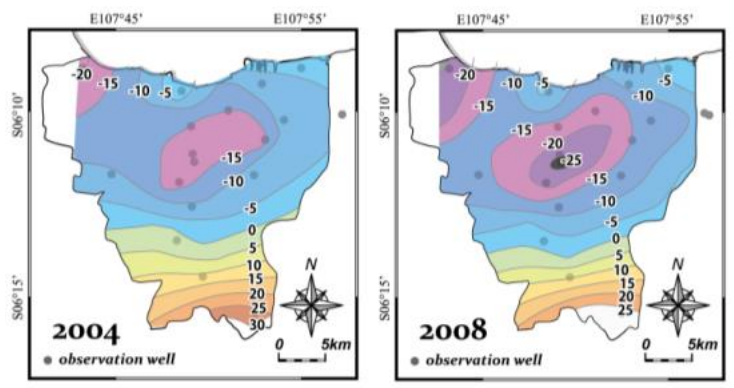

Gambar 10 Perubahan historis muka air tanah (mdpl) (Delinom, et al, 2010)

b. Pemodelan Intrusi Air Asin

Batasan distribusi intrusi air asin pada pemodelan ini ber-pedoman pada PERATURAN MENTERI KESEHATAN Nomor : 492/MENKES/PER/IV/2010 tentang Syaratsyarat dan Pengawasan Kualitas Air Asin, bahwa standar kualitas air minum salah satunya memiliki kadar Klorida maksimum 250 mg/l.

Hasil-hasil distribusi sebaran intrusi air asin dari setiap lapisan akuifer pada pada kondisi eksistng (skenario 3) dapat dilihat pada gambargambar berikut ini.

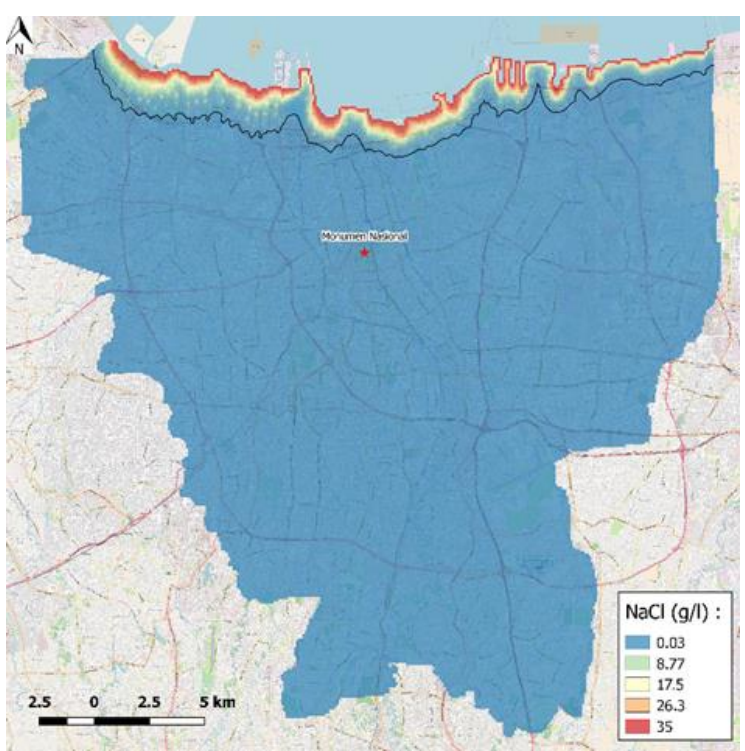

Gambar 11 Intrusi air asin akuifer tak tertekan skenario 3

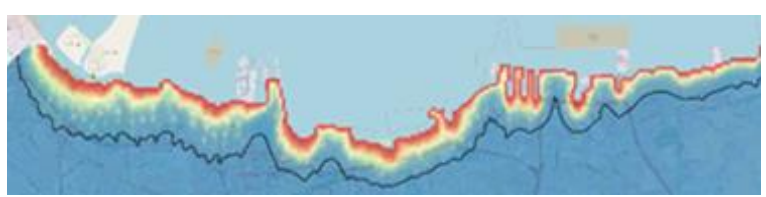

Tabel 4 Jarak intrusi air asin pada akuifer tak tertekan sekanario 3

\begin{tabular}{l|c}
\hline \multicolumn{1}{c|}{ Wilayah } & Jauh Intrusi (m) \\
\hline Kecamatan Penjaringan & 2,216 \\
Kecamatan Pademangan & 1,556 \\
Kecamatan Cilicing & 1,039 \\
\hline
\end{tabular}

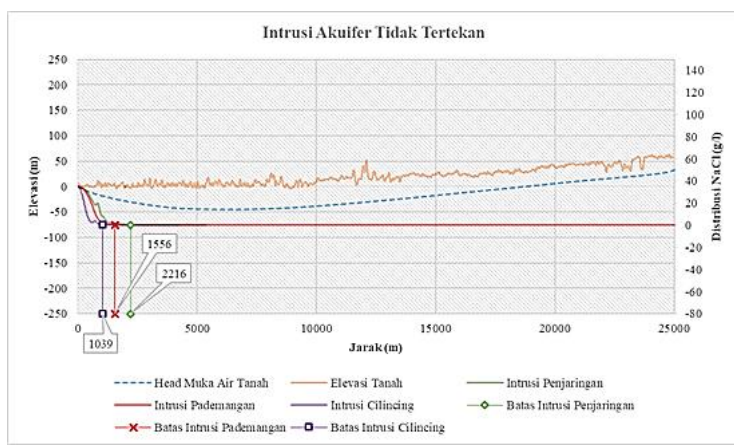

Gambar 13 Potongan melintang intrusi akuifer tak tertekan skenario 3

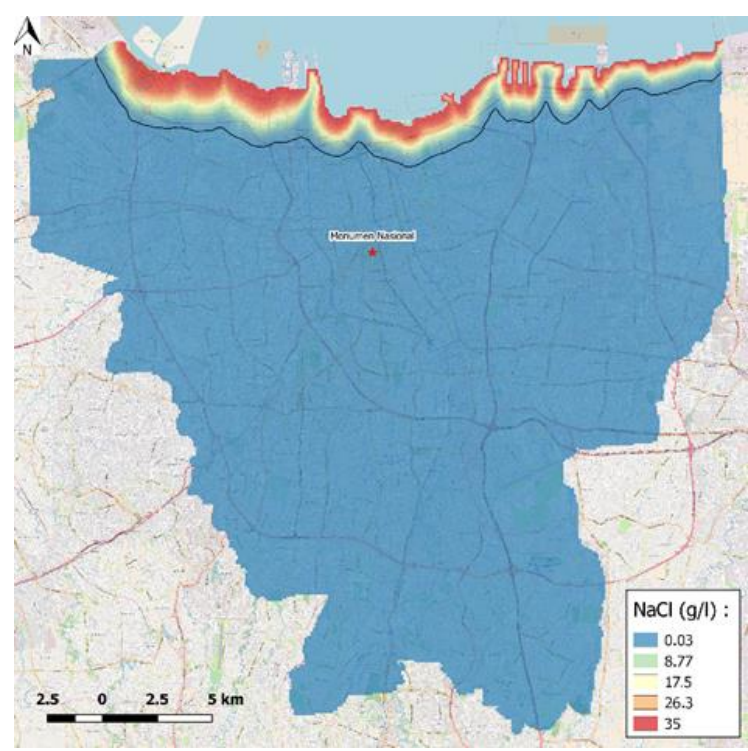

Gambar 14 Intrusi air asin akuifer tertekan atas pada skenario 3

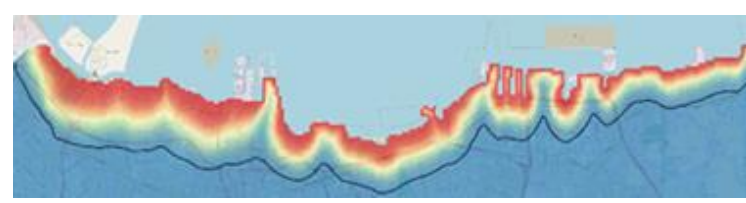

Gambar 15 Intrusi area Jakarta Utara pada akuifer tertekan atas skenario 3

Gambar 12 Intrusi area Jakarta Utara pada akuifer tak tertekan skenario 3 


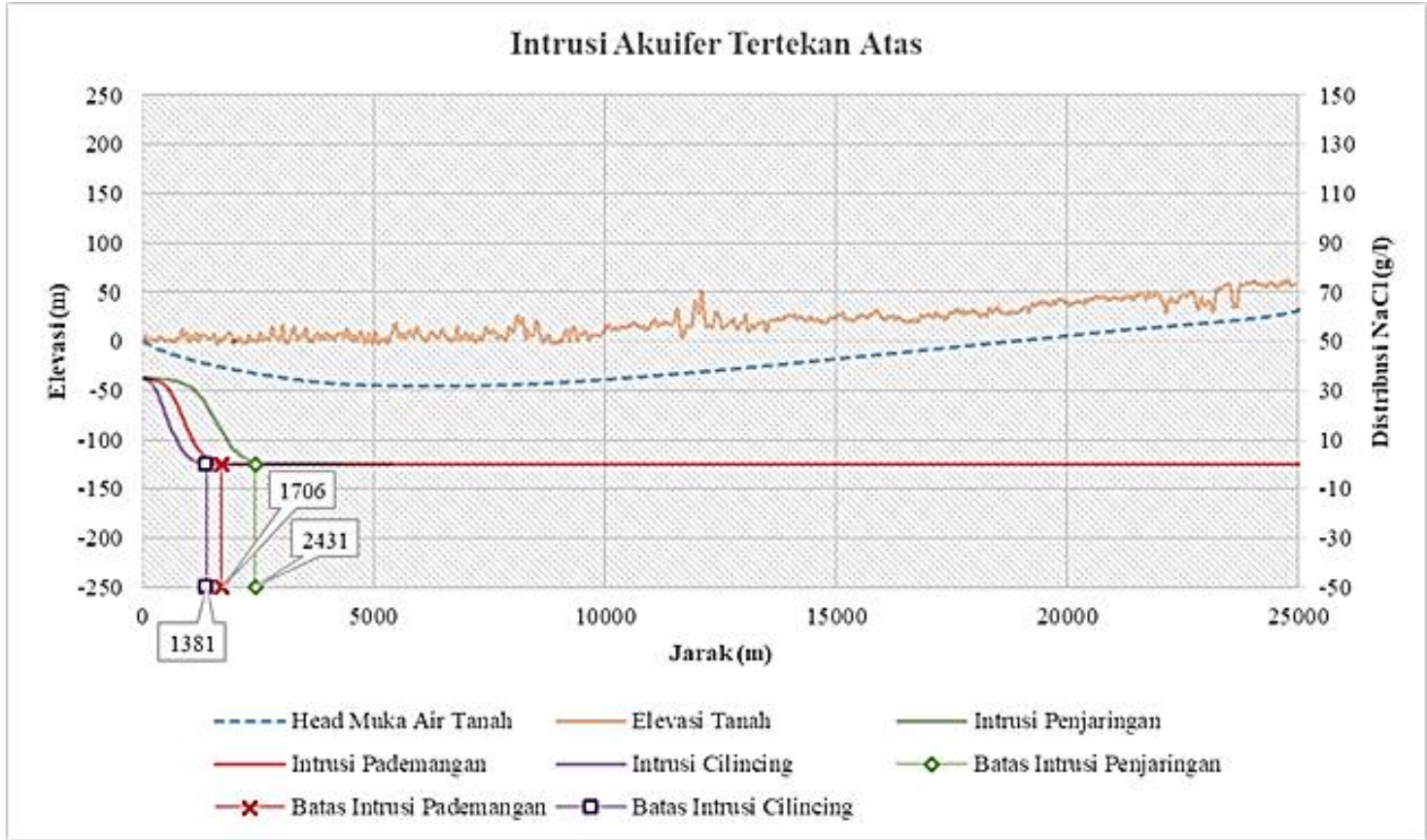

Gambar 16 Potongan melintang intrusi akuifer tertekan atas skenario 3

Tabel 5 Jarak intrusi air asin pada akuifer tertekan atas sekanario 3

\begin{tabular}{l|c}
\hline \multicolumn{1}{c|}{ Wilayah } & Jauh Intrusi (m) \\
\hline Kecamatan Penjaringan & 2,341 \\
Kecamatan Pademangan & 1,706 \\
Kecamatan Cilicing & 1,381 \\
\hline
\end{tabular}

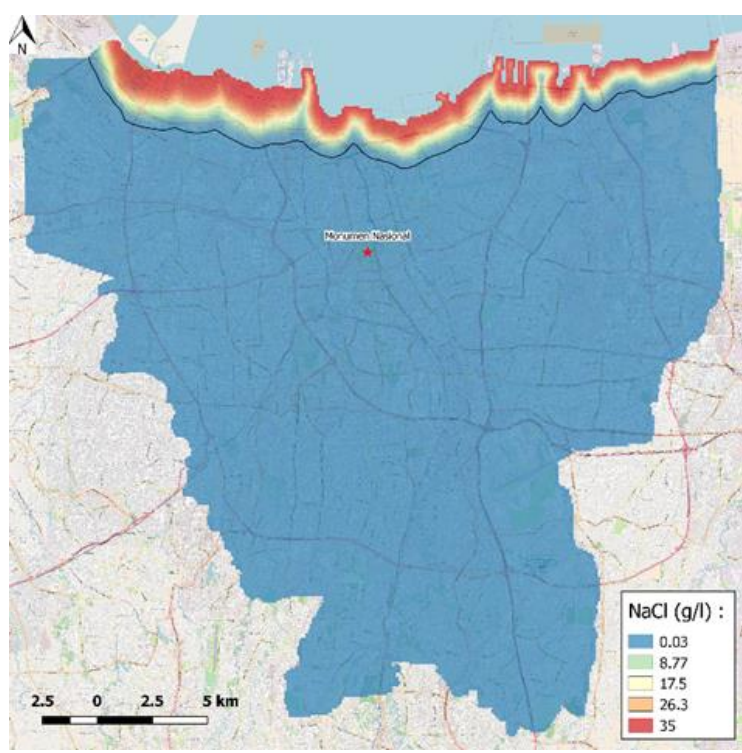

Gambar 17 Intrusi air asin akuifer tertekan tengah pada skenario 3

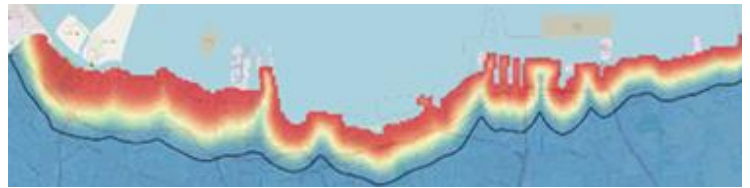

Gambar 18 Intrusi area Jakarta Utara pada akuifer tertekan tengah skenario 3

Tabel 6 Jarak intrusi air asin pada akuifer tertekan tengah sekanario 3

\begin{tabular}{l|c}
\hline \multicolumn{1}{c|}{ Wilayah } & Jauh Intrusi (m) \\
\hline Kecamatan Penjaringan & 2,502 \\
Kecamatan Pademangan & 1,768 \\
Kecamatan Cilicing & 1,510 \\
\hline
\end{tabular}

Secara keseluruhan pada akuifer tidak tertekan, dengan pengurangan penggunaan air tanah seperti pada skenario 1 dapat mengurangi intrusi yang masuk ke sistem air tanah tawar sebesar 38\%, penurunan intrusi ini sangat signifikan, ini diakibatkan pada akuifer tidak tertekan mendapat inflow langsung dari waduk dan sungai sehingga dapat mengurangi intrusi. Sedangkan dengan pengurangan penggunaan air tanah seperti pada skenario 2 dapat mengurangi intrusi sebesar 13\%.

Peningkatan penggunaan air tanah seperti pada skenario 4 dapat mendorong intrusi air asin semakin masuk ke sistem air tanah tawar sebesar 17\%. Sedangkan dengan peningkatan penggunaan air tanah seperti pada skenario 5 dapat mendorong intrusi sebesar $25 \%$. 


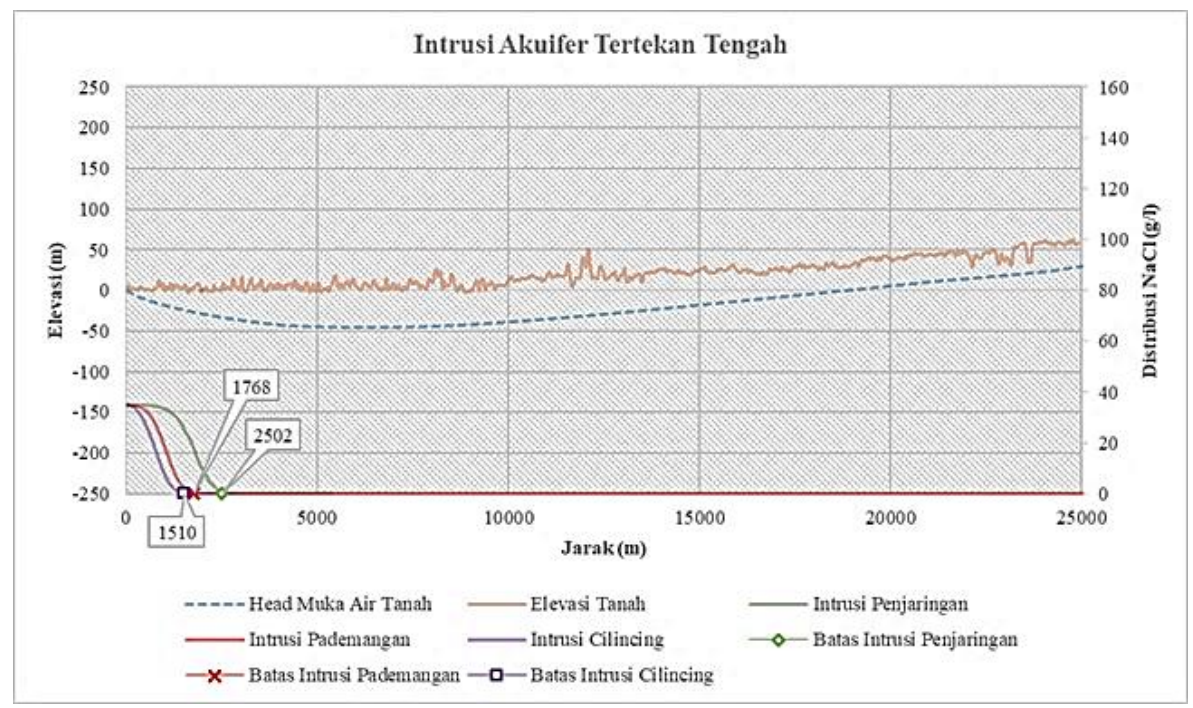

Gambar 19 Potongan melintang intrusi akuifer tertekan tengah skenario 3

Berikut adalah gambar-gambar grafik dari laju intrusi air asin yang terjadi pada setiap lapis akuifer tidak tertekan dari setiap skenario. Grafikgrafik berikut ini adalah rekapitulasi dari hasil pemodelan.

Pada akuifer tertekan atas, dengan pengurangan penggunaan air tanah seperti pada skenario 1 dapat mengurangi intrusi yang masuk ke sistem air tanah tawar sebesar 23\%, penurunan intrusi ini sangat signifikan. Sedangkan dengan pengurangan penggunaan air tanah seperti pada skenario 2 dapat mengurangi intrusi sebesar 8\%.

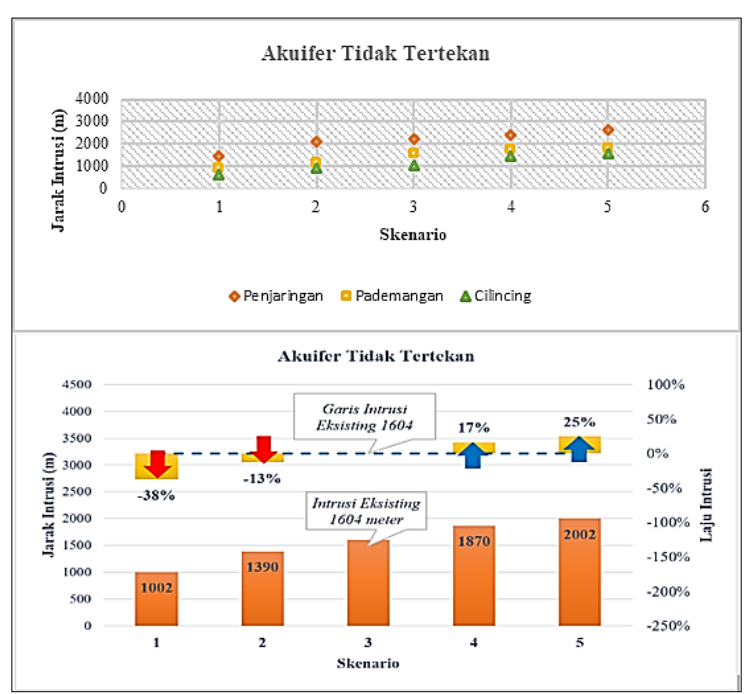

Gambar 20 Laju intrusi air asin pada akuifer tak tertekan

Peningkatan penggunaan air tanah seperti pada skenario 4 dapat mendorong intrusi air asin semakin masuk ke sistem air tanah tawar sebesar 19\%. Sedangkan dengan peningkatan penggunaan air tanah seperti pada skenario 5 dapat mendorong intrusi sebesar $26 \%$.

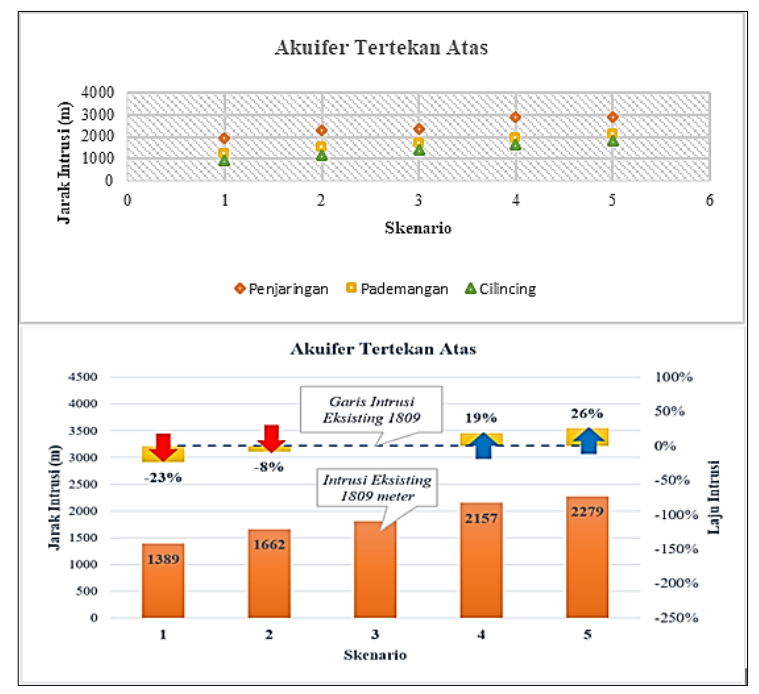

Gambar 21 Laju intrusi air asin pada akuifer tertekan atas

Pada akuifer tertekan tengah, dengan pengurangan penggunaan air tanah seperti pada skenario 1 dapat mengurangi intrusi yang masuk ke sistem air tanah tawar sebesar 23\%, penurunan intrusi ini sangat signifikan. Sedangkan dengan pengurangan penggunaan air tanah seperti pada skenario 2 dapat mengurangi intrusi sebesar 9\%.

Peningkatan penggunaan air tanah seperti pada skenario 4 dapat mendorong intrusi air asin semakin masuk ke sistem air tanah tawar sebesar 16\%. Sedangkan dengan peningkatan penggunaan air tanah seperti pada skenario 5 dapat mendorong intrusi sebesar $22 \%$. 


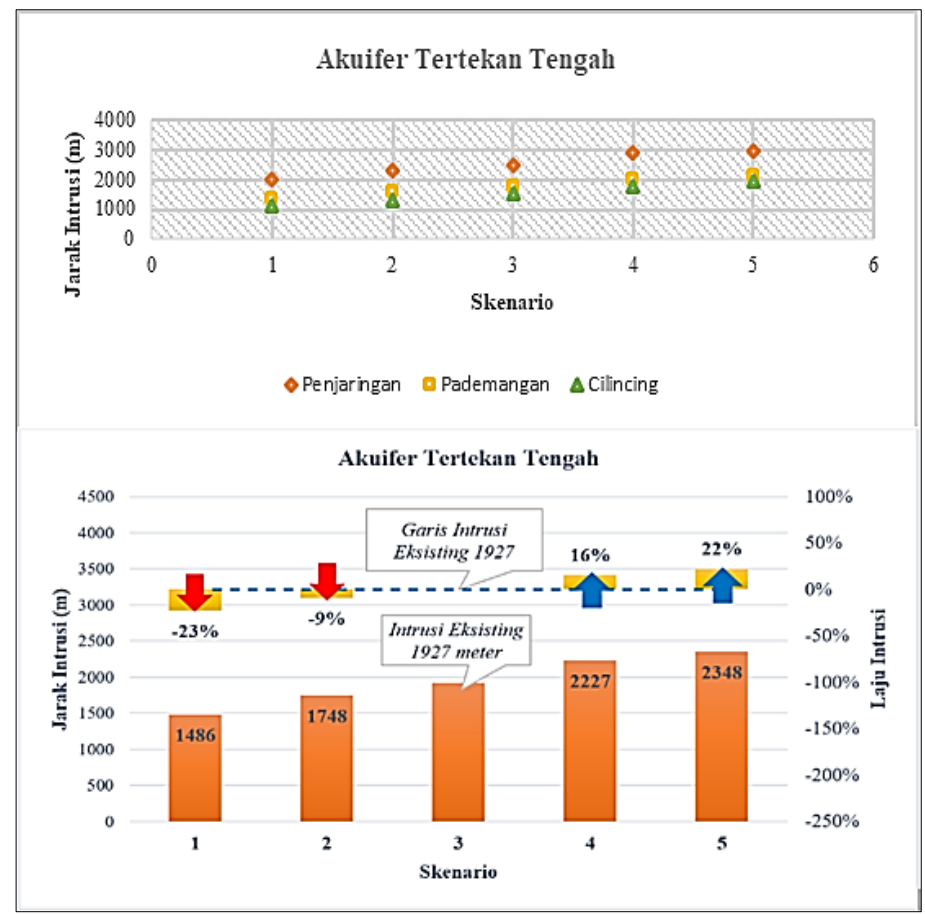

Gambar 22 Laju intrusi air asin pada akuifer tertekan tengah

\section{c. Kalibrasi Pemodelan FREEWAT}

Pada pemodelan dengan menggunakan FREEWAT digunakan kondisi awal untuk kadar garam minimum yaitu $30 \mathrm{mg} / \mathrm{l}$ dan maksimum $35000 \mathrm{mg} / \mathrm{l}$. Untuk mengetahui kesesuaian kadar garam di lapangan dan model digunakan metode Chi-Square, dengan membagi kelas data untuk analisis lebih lanjut yaitu sebagai berikut.

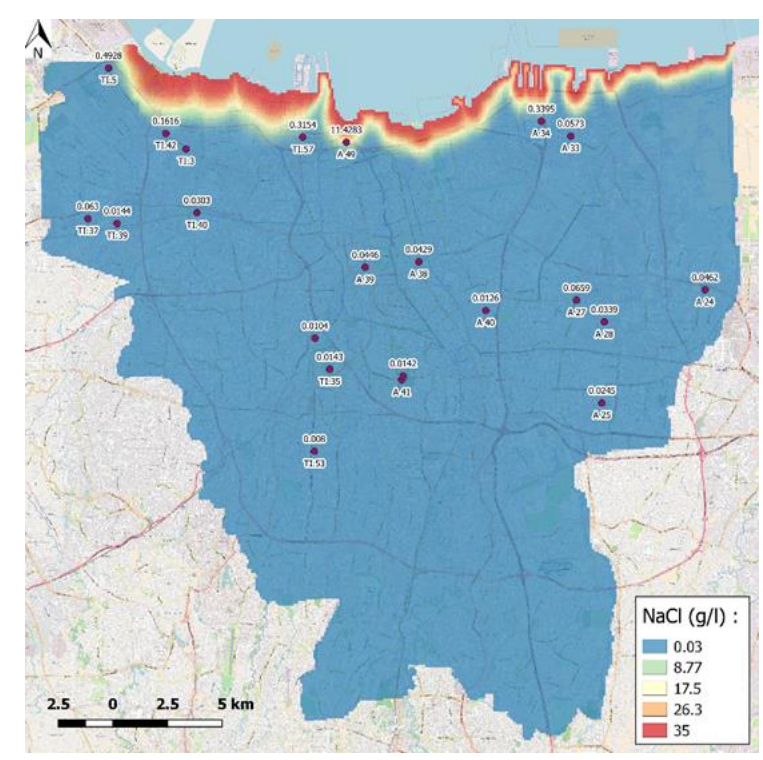

Gambar 23 Lokasi sumur untuk kalibrasi pada akuifer tertekan
Tabel 7 Pembagian kelas data untuk analisis Chi-Square

\begin{tabular}{lrc}
\hline \multicolumn{1}{c}{ Jenis Air } & \multicolumn{1}{c}{$\mathrm{Cl}^{-}(\mathrm{mg} / \mathrm{l})$} & Kelas \\
\hline Segar & $30-150$ & 1 \\
Segar-Payau & $150-300$ & 2 \\
Payau & $300-1.000$ & 3 \\
Payau-Asin & $1.000-10.000$ & 4 \\
Asin & $10.000-20.000$ & 5 \\
Sangat Asin & $>20.000$ & 6 \\
\hline
\end{tabular}

Tabel 8 Cross Tabulation

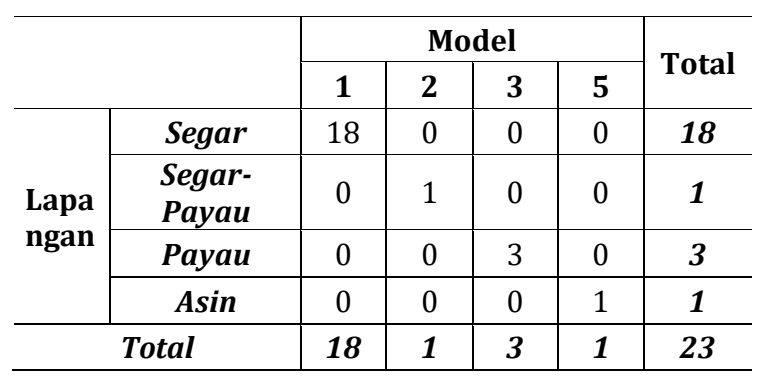

Setelah dianalisis dengan menggunakan metode Chi-Square diperoleh nilai Asymp. Sig lebih kecil dari batas kritis yaitu $0.00<0.05$ maka dapat disimpulkan hasil dari pemodelan memiliki kesesuaian dengan data di lapangan. 
Jurnal Teknik Hidraulik Vol. 10 No.1, Juni 2019: 15-28

Tabel 9 Hasil uji Chi-Square

\begin{tabular}{lrrr}
\hline & Value & df & \multicolumn{2}{c}{$\begin{array}{c}\text { Asymp. Sig. } \\
\text { (2-sided) }\end{array}$} \\
\hline Pearson Chi-Square & $69.000^{\mathrm{a}}$ & 9 & .000 \\
Likelihood Ratio & 33.588 & 9 & .000 \\
Linear-by-Linear Association & 22.000 & 1 & .000 \\
N of Valid Cases & 23 & & \\
\hline
\end{tabular}

Tabel 10 Kadar garam (Klorida) model dan lapangan

\begin{tabular}{|c|c|c|c|c|c|}
\hline \multirow{2}{*}{ No. } & \multirow{2}{*}{ Kode Contoh } & \multirow{2}{*}{ Jenis Sumur } & \multicolumn{2}{|c|}{$\mathrm{NaCl}^{-}(\mathrm{mg} / \mathrm{l})$} & \multirow{2}{*}{ Klasifikasi } \\
\hline & & & Lapangan & Model & \\
\hline 1 & A 24 & Pantau & 46.200 & 30.000 & Segar \\
\hline 2 & A 25 & Pantau & 24.500 & 30.000 & Segar \\
\hline 3 & A 27 & Pantau & 65.900 & 30.000 & Segar \\
\hline 4 & A 28 & Pantau & 33.900 & 30.000 & Segar \\
\hline 5 & A 33 & Pantau & 57.300 & 30.000 & Segar \\
\hline 6 & A 34 & Pantau & 339.500 & 366.407 & Payau \\
\hline 7 & A 38 & Pantau & 42.900 & 30.000 & Segar \\
\hline 8 & A 39 & Pantau & 44.600 & 30.000 & Segar \\
\hline 9 & A 40 & Pantau & 12.600 & 30.000 & Segar \\
\hline 10 & A 41 & Pantau & 30.000 & 30.000 & Segar \\
\hline 11 & A 42 & Pantau & 14.200 & 30.000 & Segar \\
\hline 12 & A 49 & Pantau & 11428.300 & 11345.228 & Asin \\
\hline 13 & TI.3 & Pantau & 12.500 & 30.000 & Segar \\
\hline 14 & TI.5 & Pantau & 492.800 & 466.630 & Payau \\
\hline 15 & TI.35 & Pantau & 16.000 & 30.000 & Segar \\
\hline 16 & TI.36 & Pantau & 14.300 & 30.000 & Segar \\
\hline 17 & TI.37 & Produksi & 63.000 & 30.000 & Segar \\
\hline 18 & TI.39 & Produksi & 14.400 & 30.000 & Segar \\
\hline 19 & $\mathrm{TI} .40$ & Produksi & 30.300 & 30.000 & Segar \\
\hline 20 & TI.42 & Produksi & 161.600 & 144.126 & Segar-Payau \\
\hline 21 & TI.51 & Pantau & 10.400 & 30.000 & Segar \\
\hline 22 & TI.53 & Pantau & 8.000 & 30.000 & Segar \\
\hline 23 & TI.57 & Pantau & 315.400 & 397.309 & Payau \\
\hline
\end{tabular}

Berdasarkan data di atas dapat dilihat bahwa terdapat 18 sumur yang memiliki air segar, 1 sumur memiliki air segar-payau, 3 sumur memiliki air payau, dan 1 sumur memiliki air asin.

\section{KESIMPULAN}

Berdasarkan hasil simulasi aliran air tanah dan intrusi air asin pada wilayah Jakarta dapat dilihat bahwa dengan meningkatnya pengambilan air tanah dan pengurangan pengambilan air tanah sangat berpengaruh pada muka air tanah dan penyusupan air laut ke sistem akuifer air tanah tawar. Hasil simulasi aliran air tanah pada skenario 1 , skenario 2 , skenario 3 , skenario 4, dan skenario 5 mengalami depresi pada daerah Jakarta Barat dan Jakarta Timur. Hasil simulasi memang tidak $100 \%$ akurat dikarenakan keterbatasan data, dikarenakan pemodelan dilakukan dengan menggunakan datadata yang tidak seragam. Akan tetapi hal yang 
menjadi perhatian utama pada pemodelan ini adalah metode yang digunakan untuk mengetahui bahwa dengan meningkatnya pengambilan air tanah terutama air tanah dalam melalui pemompaan mengakibatkan penurunan muka air tanah secara signifikan dan secara langsung membuat penyusupan air laut yang semakin jauh ke arah daratan karena berkurangnya tinggi tekan air tawar. Begitu pula dengan pengurangan penggunaan air tanah dapat meredam intrusi air asin ke dalam sistem akuifer air tanah tawar.

Hal tersebut dapat terlihat pada hasil pemodelan yang dilakukan pada 5 skenario. Dari 5 skenario pemodelan tersebut menunjukan bahwa begitu besarnya pengaruh pengurangan dan peningkatan penggunaan air tanah terhadap laju intrusi, terutama pada akuifer tak tertekan.

Pemodelan yang dilakukan pada FREEWAT parameter yang digunakan adalah $\mathrm{NaCl}$ dari air laut, sehingga sifat asin pada pemodelan FREEWAT hanya berdasarkan parameter $\mathrm{NaCl}$ saja. Distribusi sebaran intrusi air asin yang terjadi pada pemodelan FREEWAT dikarenakan berkurangannya tekanan air tanah tawar akibat dari pemompaan sehingga mengganggu tekanan air tanah tawar dan membuat parameter $\mathrm{NaCl}$ masuk kedalam sistem akuifer air tanah tawar yang menyebabkan intrusi air asin.

\section{UCAPAN TERIMA KASIH}

Ucapan terima kasih kami tujukan kepada Pimpinan dan Staf dari Balai Konservasi Air Tanah atas kerja sama dan bantuannya dalam menyediakan data sehingga penelitian ini dapat terlaksana.

\section{DAFTAR PUSTAKA}

BPS. (2018). Berapa Jumlah Penduduk Jakarta? Retrieved, 2018, from Katadata: https://databoks.katadata.co.id/datapublish/20 18/01/24/berapa-jumlah-penduduk-jakarta

Delinom, R., Lubis, R. F., Shimada, J., \& Taniguchi, M. (2010). Groundwater Characteristic in Jakarta Area, Indonesia. ResearchGate. http://DOI:10.14203/risetgeotam2010.v20.35

Filippis, G. D., Ghetta, M., Neumann, J., Cardoso, M., Cannata, M., Borsi, I., \& Rossetto, R. (2017). FREEWAT User Manual (Vol. 1). Retrieved from http://www.freewat.eu/sites/default/files/FREE WAT vol1.pdf

Geomagz. (2014). Air Tanah dan Pembangunan Bawah Tanah Jakarta. Retrieved 2018, from http://geomagz.geologi.esdm.go.id/air-tanahdan-pembangunan-bawah-tanah-jakarta/
Guo, W., \& Langevin, C. D. (2002). User's Guide to SEAWAT: A Computer Program for Simulation of Three-Dimensional Variable-Density GroundWater Flow. Florida: U.S. Geological Survey. Retrieved from https://fl.water.usgs.gov/PDF files/twri 6 A7 guo langevin.pdf

Harbaugh, A. W. (2005). MODFLOW-2005, The U.S. Geological Survey Modular Ground-Water Model-the Ground-Water Flow Process. Virginia: U.S. Geological Survey. Retrieved from http://inside.mines.edu/ epoeter/583CSM/DO C4 MODFLOW2005-TM6A16.pdf

Herlambang, A., \& Indriatmoko, R. H. (2005). Pengelolaan Air Tanah dan Intrusi Air Laut. Jurnal Air Indonesia, 1. Retrieved from http://ejurnal.bppt.go.id/ejurnal2011/index.ph $\mathrm{p} / \mathrm{JAl} /$ article/view/42/43

Indriatmoko, R. H. (2012). Kajian Intrusi Air Asin pada Sistem Akuifer Jakarta. Institut Pertanian Bogor, Magister Sains pada Program Studi Pengelolaan Daerah Aliran Sungai (DAS). Bogor: Institut Pertanian Bogor. Retrieved from http://repository.ipb.ac.id/jspui/bitstream/123 456789/61513/1/2012rhi.pdf

Matahelumual, B. C. (2010). Kajian Kondisi Air Tanah Jakarta Tahun 2010. Jurnal Lingkungan dan Bencana Geologi, 1, 131- 149. Retrieved from http://www.bgl.esdm.go.id/publication/index.p $\mathrm{hp} /$ dir/article download/288

Mukhtar, O., Pranantya, P. A., \& Hadian, S. D. (2016). Manajemen Air Tanah Di Cekungan Air Tanah DKI Jakarta. In Seminar Nasional ke-III Fakultas Teknik Geologi Universitas Padjadjaran. Retrieved from http://seminar.ftgeologi.unpad.ac.id/wpcontent/uploads/2016/07/2.15.pdf

Nimmo, J. R. (2004). Porosity and Pore Size Distribution. Encyclopedia of Soils in the, 3, 295 303. Retrieved from https://wwwrcamnl.wr.usgs.gov/uzf/abs_pubs/ papers/nimmo.04.encyc.por.ese.pdf

Roover, S. d. (2015). Modeling the Jakarta Groundwater System : A Sensitivity Analysis. Universiteit Twente, Civi Engineering. Twente: Universiteit Twente. Retrieved from http://essay.utwente.nl/68510/1/Roover-Samde.pdf 
Jurnal Teknik Hidraulik Vol. 10 No.1, Juni 2019: 15-28

Setiawan, T., Yermia, E., Purnomo, B. J., \& Tirtomihardjo, H. (2017). Intrusi Air Lut pada Sistem Akuifer Tertekan Cekungan Air Tanah Jakarta Berdasarkan Analisis Hidrokimia dan Hidroisotop. Riset Geologi dan Pertambangan, 27, 1 - 14. http://doi:10.4203/risetgeotam 2017.v27.430

Wahyudi, F. R., \& Moersidik, S. S. (2015). The Analysis of Groundwater Availability and Utility in DKI Jakarta. ScienceDirect, $799 \quad$ - 807. https://doi.org/10.1016/j.sbspro.2016.06.1 $\underline{48}$
Wandowo, dkk. (2001). Daerah Resapan Air Tanah Cekungan Jakarta. In Risalah Pertemuan IImiah Penelitian dan Pengembangan Aplikasi Isotop dan Radiasi. Retrieved from https://ansn.bapeten.go.id/files/41301/2312.p df 